\title{
Pendampingan Keterampilan Berkomunikasi Public Speaking dalam Mendukung Pemasaran Produk UMKM Desa Gedawang Banyumanik Semarang
}

\author{
${ }^{1}$ Dian Marhaeni Kurdaningsih, ${ }^{2}$ Choiril Anwar* \\ ${ }^{1}$ Prodi Ilmu Komunikasi, Universitas Islam Sultan Agung, Semarang, Indonesia \\ ${ }^{2}$ Prodi Pendidikan Bahasa Inggris, Universitas Islam Sultan Agung, Semarang, Indonesia \\ *Corresponding Author: \\ Jl. Kaligawe Raya Km 4 Semarang 50112, Indonesia \\ Email: choirilanwar@ unissula.ac.id \\ Received: \\ Revised: \\ Accepted: \\ Published: \\ 28 April 2020 \\ 1 December 2020 \\ 15 December 2020 \\ 29 December 2020
}

\begin{abstract}
Abstrak
Desa Gedawang Banyumanik Semarang memiliki banyak potensi. Di saat usaha melimpah mereka memanen hasil bumi akan tetapi sebagian dari mereka mendirikan usaha berbasis UMKM (Usaha Mikro, Kecil dan Menengah) dari berbagai sektor. Peluang ini menciptakan masyarakat berinisiatif membangun usaha home industry. Tantangan para pengusaha home industry ini memproduksi produknya berdasarkan banyak sedikitnya pesanan. Mereka belum memanfaatkan media promosi sebagai sarana pemasaran. Beberapa alasan yang muncul diantaranya adalah karena belum dikuasainya teknologi informasi. Kegiatan ini bertujuan memberikan pemahaman dan keterampilan berkomunikasi berupa public speaking kepada warga Gedawang dalam upaya peningkatan standar mutu dan kesejahteraan UMKM mereka. Pendampingan dilakukan dalam bentuk pelatihan public speaking dan pendampingan pelaksanaan pemasaran dengan mengandalkan keterampilan public speaking hingga mampu memasarkan secara mandiri. Pendampingan juga dilakukan dalam bentuk mencarikan relasi atau channel pemasaran agar produk-produk UMKM ini dikenal di masyarakat luas. Dari hasil pelaksanaan kegiatan pendampingan ini diharapkan warga dapat melakukan presentasi, wawancara atau menyampaikan laporan yang lebih baik setelah mengikuti kegiatan ini.
\end{abstract}

Kata Kunci: Public speaking; UMKM

\begin{abstract}
Gedawang Village Banyumanik Semarang has a lot of potential. When the business is abundant they harvest agricultural products, but some of them establish SMEs (Small and Medium Enterprises) from various sectors. This opportunity creates the community to take the initiative to build a home industry business. The challenge for home industry entrepreneurs is to produce their products based on the number
\end{abstract}


of orders. They have not used promotional media as a marketing tool. Some of the reasons that arise include the lack of mastery of information technology. This activity aims to provide understanding and communication skills in the form of public speaking to Gedawang residents in an effort to improve quality standards and the welfare of their SMEs. Assistance is carried out in the form of public speaking training and mentoring in marketing implementation by relying on public speaking skills to be able to market independently. Assistance is also carried out in the form of finding relationships or marketing channels so that SMEs products are known to the wider community. From the results of the implementation of this assistance activity, it is hoped that residents can make presentations, interviews or submit better reports after participating in this activity.

Keywords: Public Speaking; SMEs

\section{PENDAHULUAN}

UMKM (Usaha Mikro, Kecil dan Menengah) memiliki peranan dan kontribusi yang sangat penting bagi perekonomian Indonesia. UMKM berkontribusi dalam menciptakan investasi nasional, Produk Domestik Bruto (PDB) Nasional, penyerapan tenaga kerja nasional, dan penciptaan devisa nasional (Humaira, 2018). Agar sebuah UMKM dapat tumbuh dan berkembang serta siap menghadapi pasar bebas ASEAN, diperlukan upayaupaya yang strategis dari para pemilik dan stakeholder-nya. Pengetahuan dan literasi keuangan punya pengaruh besar terhadap keberlangsungan UMKM (Aribawa, 2016; Humaira, 2018). Kualitas pelayanan petugas pajak, sanksi perpajakan dan biaya kepatuhan pajak serta perlindungan hukum (advokasi) terhadap pelaku UMKM juga mempengaruhi perputaran rodanya (Fuadi \& Mangoting, 2013; Arliman, 2017). Selain itu, perlu juga dilakukan, menurut Hamdy (2001), perencanaan dan kegiatan operasional yang terpadu atau yang disebut dengan Sustained Competitive Advantage Strategy (SCA) yang punya tujuan baik jangka pendek maupun panjang guna mempertahankan atau bahkan meningkatkan sustainable real income secara efektif dan efisien (Sudaryanto, Ragimun, \& Wijayanti, 2013). Tak kalah penting dari itu semua adalah pemasaran. Pemasaran yang baik, yang disokong dengan komunikasi pemasaran terpadu (Chrismardani, 2014) dapat meningkatkan daya saing UMKM (Wibowo \& Arifin, 2015). Salah satunya dengan pengetahuan dan keterampilan public speaking. Public speaking adalah presentasi formal berkelanjutan yang dilakukan seseorang kepada pendengarnya (Verderber, Verderber, \& Sellnow, 2011). Komunikasi dengan seni public speaking yang baik tanpa gugup (Raja, 2017) oleh pelaku UMKM dapat meyakinkan para konsumen dan pihak-pihak yang berkolaborasi (Lucas, 2009; Parvis, 2001) sehingga tumbuhlah kepercayaan itu.

Wilayah kelurahan Gedawang masuk kategori daerah yang subur. Daerah pegunungan yang terdiri dari hamparan tanah merah yang gembur sangat cocok untuk berbagai jenis tanaman terutama buah dan sayur. Tentu saja ini memacu masyarakat untuk mendirikan berbagai unit usaha yang didukung hasil bumi. Di samping itu juga muncul bentuk usaha lainnya sebagai bentuk kreativitas dan produktivitas sebagian masyarakat.

182 || Indonesian Journal of Community Services 
Berbagai jenis usaha diproduksi oleh UMKM di Kelurahan Gedawang. Beberapa usaha mengandalkan hasil pertanian masyarakat setempat seperti usaha criping singkong, kripik pisang, pengeringan temu giring dan beberapa usaha lain semisal krupuk tepung gandum dan camilan. Usaha lain yang berbasis home industry ini adalah usaha keterampilan seperti pengolahan kayu untuk perkakasa rumah tangga, keterampilan pembuatan pohon hias berdaun plastik kombinasi kayu alam dan lainnya.

Prospek penjualan selama ini cukup dengan melayani permintaan pesanan lokal. Beberapa pesanan telah menjangkau mereka yang berasal dari luar daerah namun jumlahnya masih terbatas. Sistem promosi dan penjualan memang masih mengandalkan mulut ke mulut. Masyarakat notabene belum memanfaatkan teknologi yang ada. .Disamping karena alasan terbatasnya alat teknologi juga penguasaan alat teknologi yang belum ada. Dari segi keterampilan berkomunikasi, masyarakat juga belum memiliki keterampilan berkomunikasi secara fasih. Sebagai contoh bagaimana teknik melobi dan menegosiasi yang baik. Sedangkan pergaulan pemasaran saat ini sangat bergantung pada keterampilan komunikasi. Melakukan keterampilan komunikasi yang fasih akan mampu mendukung dalam memasuki pasar-pasar besar. Dengan keterampilan komunikasi masyarakat pengelola UMKM akan tampil percaya diri dan supel dalam meluaskan jaringan komunikasi.

Masih minimnya keterampilan komunikasi ini membuat anggota UMKM sering menolak peluang beberapa jenis bantuan pengembangan usaha dari kelurahan. Salah satu alasan adalah takut atau tidak percaya diri jika harus menyusun proposal, harus presentasi, harus diwawancarai, atau harus melaporkan secara lisan maupun tulisan. Minim komunikasi juga berdampak pemasaran tidak optimal karena terkendala minimnya jaringan usaha dan minimnya akses media massa.

Mitra dalam kegiatan pelatihan dan pendampingan ini adalah Ibu Kuslani atau Ketua Kelompok PKK RW 2 Gedawang Banyumanik Semarang. Beliau adalah pemimpin yang mengkoordinir seluruh kegiatan perekonomian berbasis UMKM di wilayah Gedawang. Selama ini $\mathrm{Bu}$ Kuslani turut memotivasi, mengarahkan dan memberikan informasi berkenaan dengan kebijakan desa dan usaha melalui beberapa kegiatan. Kegiatan di tingkat desa terselenggara dalam beberapa wadah seperti rapat desa dan pertemuan kelompok PKK, taklim bapak-bapak, taklim ibu-ibu yang sudah stabil dan berjalan secara rutin. Dalam wadah inilah komunikasi dalam berbagai hal dilakukan dalam rangka mencari solusi, mulai dari rencana pembangunan sampai dengan permasalahan keluarga.

Mitra kedua dalam kegiatan pendampingan ini adalah Ibu Musyarofah selaku Ketua kelompok PKK RW2 Gedawang yang membawahi beberapa pelaku usaha berbasis UMKM ini. Bu Winarto tercatat sebagai golongan muda yang aktif memajukan desa tempat beliau tinggal dengan cara mencarikan peluang usaha dan membantu mengembangkan usaha terutama dengan pihak luar seperti melalui perguruan tinggi. Ibu Musyarofah dekat dan dipercaya warganya untuk membantu berbagai hal. Salah satunya adalah mencarikan solusi pengembangan usaha UMKM ini. 
Adapun kondisi wilayah tempat melakukan program adalah:

Kelurahan Gedawang Kecamatan Banyumanik Kota Semarang memiliki luas wilayah, 50, $68 \mathrm{Ha}$, yang dibatasi oleh:

* Sebelah Utara : Kelurahan Padangsari dan Kelurahan Pedalangan

* Sebelah Timur : Kelurahan Jabungan

* Sebelah Selatan : Kelurahan Pudakpayung dan Kabupaten Semarang

* Sebelah Barat : Kelurahan Banyumanik dan Kelurahan Pudakpayung

Kelurahan ini meliputi 9 RW dan 38 RT.

Secara Demografis, Kelurahan Gedawang terbagi menjadi 09 RW dan 49 RT yang berada tersebar di wilayah kelurahan tersebut. Jumlah penduduk di masing-masing RT tidak sama, masing-masing antara 35 s/d $45 \mathrm{KK}$, jika dihitung rata-rata per RT memiliki jumlah 40 KK Per RT. Adapun jumlah penduduk Kelurahan Gedawang menurut umur dan jenis kelamin adalah sebagai berikut:

Data Monografi Kelurahan Gedawang , Bulan Desember Tahun 2009.

Jumlah penduduk laki-laki : 1.976 jiwa

Jumlah penduduk perempuan : 1.987 jiwa

Jumlah Kepala Keluarga : $1.010 \mathrm{KK}$

Jumlah Total Penduduk : 3.963 jiwa

Kelurahan Gedawang memiliki kondisi ekonomi dan budaya yang unik karena hampir $50 \%$ kondisi masyarakat saat ini berasal dari kalangan pendatang. Perluasan wilayah proyek jalan Tol Semarang Bawen telah merubah struktuk wilayah, ekonomi dan budaya kelurahan ini. Jalan beraspal menjadi lebih lebar dan halus, hal ini diiringi pula dengan banyaknya developer yang mulai mengembangkan wilayah ini menjadi perumahan-perumahan yang dihuni oleh para pendatang.

Masyarakat asli Gedawang sangat memegang nilai-nilai budaya setempat seperti adat sedekah bumi dan peringatan hari besar agama yang dirayakan secara tradisional. Kondisi ini berbeda dengan tradisi para pendatang yang lebih menyukai kegiatankegiatan modern seperti olah raga, kerja bakti dan lainnya.

Sumber daya alam Kelurahan Gedawang didukung dengan kondisi alam yang berpegunungan. Gedawang memiliki jenis tanah gempal berwarna coklat kemerahan. Kondisi ini menguntungkan petani karena lahan tanah yang subur dan kualitas air yang bening untuk kepentingan warga. Dengan memanfaatkan tanah persawahan yang tersisa dan hutan di lereng pegunungan sangat produktif di tanami warga dengan padi, jagung, singkong dan rempah-rempah terutama temu giring, dan kunyit. Lahan pekarangan juga sangan produktif karena dengan lahan perkampungan di desa hampir setiap warga memiliki tanaman buah. Sentra buah yang terkenal adalah durian dan rambutan yang sudah terkenal ciri khasnya di Semarang.

Hasil bumi, berupa padi, jagung, singkong, buah buahan seperti durian, ace, rempah-rempah, seperti temu giring dan kunyit, tanaman kebun seperti petai, jengkol, serta hasil palawija seperti kacang tanah, kimpul, ketela. Dengan basis hasil bumi ini memunculkan usaha seperti kripik singkong, kripik pisang, kulit lumpia, peternakan ayam, kambing dan sapi. 


\section{Permasalahan prioritas mitra}

Berdasarkan analisis situasi dilingkungan mitra maka dirumuskan permasalahan antara lain:

1. UMKM sangat potensial untuk dikembangkan

2. Pengelola UMKM belum optimal melakukan pengelolaan usaha

3. Pengelola UMKM belum percaya diri dan belum termotivasi dalam pengembangan usaha

4. Pengelola UMKM belum memahami pentingnya keterampilan komunikasi dalam mendukung pemasaran usaha

5. Pengelola UMKM belum memahami keterampilan public speaking dalam mendukung pemasaran usaha

Usulan prioritas permasalahan pada kegiatan pendampingan ini adalah

1. Pengelola UMKM membutuhkan pemahaman dan kemampuan keterampilan public speaking dalam mendukung pemasaran usaha

2. Pengelola UMKM membutuhkan pendampingan praktik public speaking dalam mendukung pemasaran usaha

\section{Solusi dan target luaran}

Target luaran kegiatan program pengabdian masyarakat ini dengan program pendampingan keterampilan public speaking di Kelurahan Gedawang Semarang adalah sebagai berikut:

1. Mensosialisasikan keterampilan public speaking di masyarakat

2. Metode pendampingan pelaksanaan program pendampingan public speaking

3. Memotivasi produktivitas usaha pada UMKM

4. Menumbuhkan motivasi dan kepercayaan diri masyarakat

5. Menaikkan kesejahteraan masyarakat melalui peningkatan produktivitas UMKM

6. Peningkatan produktifitas dan kreativitas dalam usaha

7. Publikasi ilmiah jurnal nasional dan prosiding nasional.

Kegiatan ini akan menciptakan sosialisasi. Sosialisasi kegiatan dalam bentuk mengenalkan keterampilan public speaking yang dalam pemahaman maupun praktiknya masih awam bagi masyarakat. Keterampilan public speaking bersifat soft skill, masyarakat perlu dibangun kesadaran akan peran dan fungsi dalam mendukung keberhasikan pengembangan usaha UMKM.

Target metode pendampingan dimaksudkan bahwa kegiatan pengembangan produk adalah dinamis dan seni. Beberapa metode bisa diterapkan, tetapi melalui pendampingan ini akan ditemukan metode yang spesifik dan cocok bagi masyarakat Gedawang sesuai dengan latar belakang budaya dan karakter psikologis masyarakatnya.

Target memotivasi secara psikologis sehingga melalui pendampingan ini masyarakat pelaku usaha UMKM harus mampu dan sudah terbangun motivasi dan kepercayaan diri sehingga muncul sikap optimis. Sikap ini penting dalam mendukung keberhasilan usaha. 
Didukung soft skill yang kuat dan usaha yang sudah stabil pada akhirnya masyarakat akan lancar dalam menjalankan roda usaha sehingga akan tumbuh kreativitas ide-ide baru perluasan usaha sehingga produktifitaspun juga akan meningkat. Kemantapan usaha ini tentunya akan signifikan dalam meningkatkan kesejahteraan masyarakat.

Hasil kerja pendampingan ini telah ditindaklanjuti dalam riset berbasis kegiatan pengabdian masyarakat dan didesiminasi dalam jurnal pengabdian masyarakat ber-ISSN dan koran online nasional.

\section{METODE}

Tahap pertama yang dilakukan dalam pendampingan ini tim PKM bersilaturahmi kepada ketua RW dan anggota kelompok usaha. Kegiatan ini dilakukan di dua RW dengan agenda diadakan dialog tentang perkembangan usaha dan permasalahan yang dihadapi selama ini. Tim menginformasikan tentang public speaking dan arahan dalam mendukung perkembangan usaha UMKM.

Tim dan ketua RW membuat kesepakatan jadwal pertemuan dan anggota menyatakan komitmen untuk selalu hadir dalam pertemuan-pertemuan yang sudah disepakati. Kemudian tim terjun ke masyarakat mendata sekali lagi detail permasalahan mitra kepada anggota kelompok. Pada pertemuan pertama tim mengadakan sosialisasi tentang peran public speaking dalam mendukung perkembangan usaha UMKM. Tim membagikan buku praktis dasar komunikasi dan keterampilan public speaking.

Anggota kelompok mendapatkan pelatihan membangun motivasi, membangun kepercayaan diri, berpenampilan menarik, dan mampu berkomunikasi dengan baik. Masyarakat juga mendapatkan pelatihan tentang praktik berkomunikasi, tampil di depan forum, praktif teknik presentasi.Anggota kelompok akan melihat video animasi, masing-masing diberi satu CD. Untuk kelanjutan mereka mempelajari melalui CD animasi ini masing-masing kelompok akan mendapatkan satu unit computer akan bisa digunakan untuk belajar dan praktik bersama. Satu kelompok juga akan dapat satu buah mikrofon untuk mendukung praktik.

Pada tahap berikutnya diadakan bazar produk dengan mengundang sponsor dari pabrik produk kebutuhan konsumsi masyarakat. Tim mendampingi anggota UMKM untuk belajar praktik public speakingnya.Tim dan pelaku usaha akan berdialog dan melakukan konsultasi berkaitan dengan praktik tersebut.

Pada tahap selanjutnya tim akan melakukan pendampingan pengembangan usaha dengan mencarikan jaringan modal dan pemasaran. Kegiatan akan dilakukan dalam satu tahap selama satu tahun ini tim akan melakukan sampai tahap semi mandiri. 


\section{HASIL DAN PEMBAHASAN}

Kegiatan pengabdian masyarakat berupa pendampingan komunikasi public speaking dalam mendukung kegiatan UMKN Kelurahan Gedawang Banyumanik sudah berlangsung pada bulan Oktober 2020. Kegiatan dilaksanakan secara luring di depan panggung Perfomance RW 02 Gedawang. Kegiatan ini memanfaatkan pertemuan yang sudah ada, yaitu kegiatan senam sehat yang berlangsung secara rutin di tengah pandemic Covid-19. Acara senam sehat biasanya didahului dengan senam bersama bapak dan ibu di lingkungan RW 02 Gedawang. Namun peserta memang didominasi oleh ibu-ibu sedangkan bapak-bapak jumlahnya hanya terbatas. Setelah selesai acara senam sehat sesuai kelaziman, acara dilanjutkan dengan silaturrahim antar warga yang memang jarang ketemu, sesekali ada penyuluhan dari kelurahan, pemeriksaan kesehatan dan lain-lain. Berkumpulnya warga ini selalu dimanfaatkan oleh warga masyarakat dengan membawa barang dagangan seperti minuman jus buah, lauk-pauk, snack, aneka kerupuk, jamu tradisional dan lain-lain.

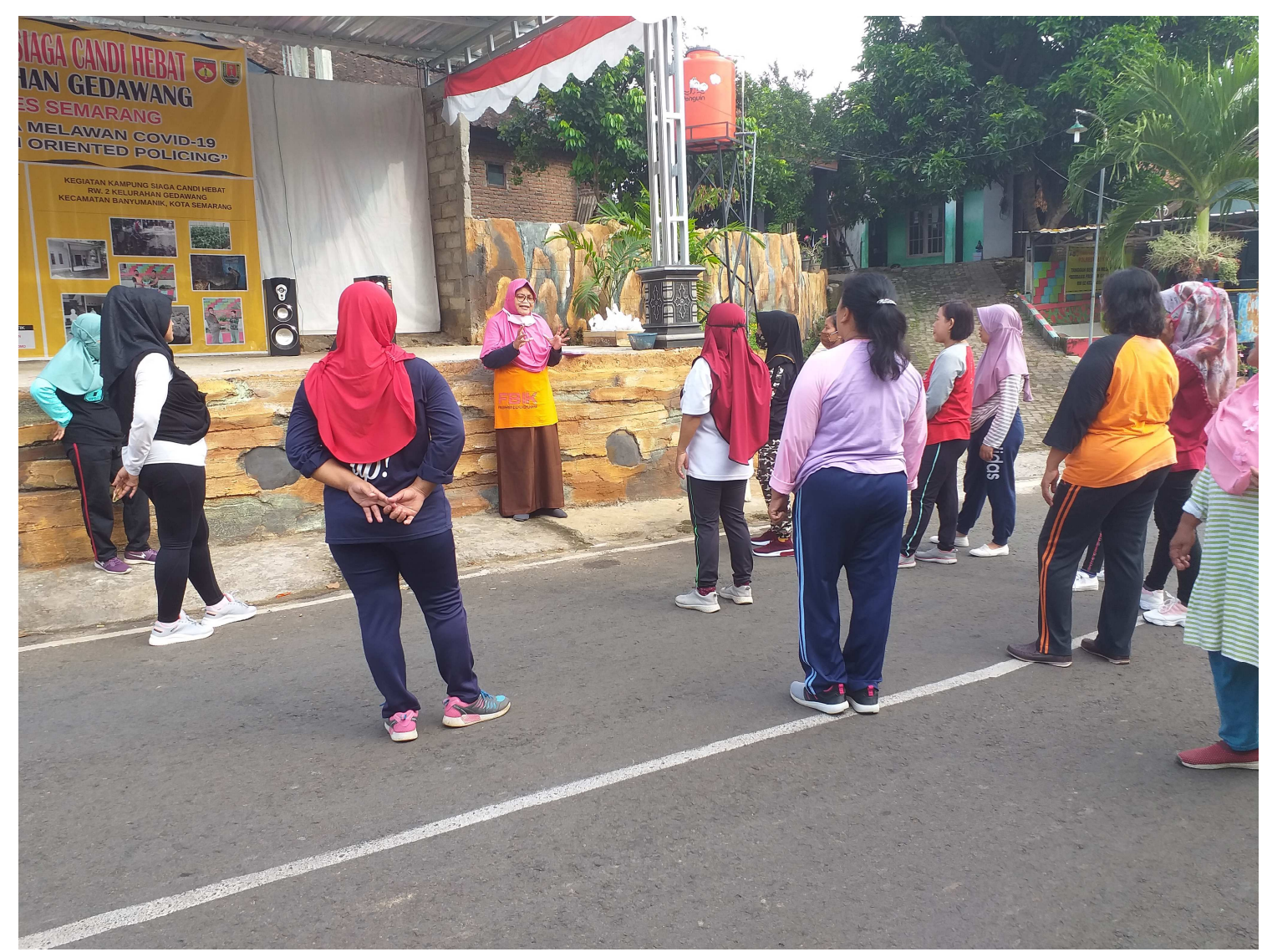

Gambar 1. Tim PKM Unissula sedang menyampaikan materi public speaking

Selama ini acara senam bersama cukup semarak dan pemanfaatan berkumpulnya warga untuk sarana jual beli menambah pertemuan di Minggu pagi lebih meriah. Kegiatan ini dihadiri sekitar 30 sampai dengan 40 warga setiap minggunya dengan koordinator langsung ibu RW 02. Acara senam dipimpin oleh instruktur senam yang 
berasal dari RW 02 sendiri sehingga ajang Senam sehat mampu mempererat tali silaturrahim. Karena alasan itulah maka kelompok masyarakat aktivis senam sehat Tim pilih untuk menjadi peserta anggota mitra pengabdian masyarakat.

Acara Pendampingan ini dimulai dengan kegiatn silaturrahim Tim ke rumah ibu RW yaitu bu Musyarofah untuk melakukan permohonan izin pendampingan. Tim berdiskusi tentang jumlah warga yang mengandalkan hidup dari wirausaha di rumah. Dari informasi ibu RW tercatar beberapa home industry atau sering disebut Usaha Masyarakat Kecil Menengah (UMKM). Ada beberapa usaha di antaranya adalah membuka warung, berjualan gas, pemasok es batu, bikin kulit lunpia, jualan snack, jualan gorengan, jualan online, laundry, bikin kerupuk, keripik, rempeyek, aneka lauk pauk dan lain-lain.

Pada prinsipnya para pengusaha UMKM ini membutuhkan keterampilan berkomunikasi dalam menawarkan dagangan atau membutuhkan keterampilan public speaking dalam mengoptimalkan penjualan. Sehingga menjadi penting untuk dilakukan pendampingan public speaking ini terutama bagi ibu-ibu muda pelau usaha. Tim mulai melaksanakan pendampingan dengan menyusun tips berkomunikasi yang baik sebagai pegangan dalam rangka memudahkan pelaksanaan usaha. Tim menyusun panduan dalam bentuk leaflat yang dibagikan kepada warga dan kemudian dilakukan sosialisasi dan dilanjutkan pendampingan pada sesi berikutnya pada acara pengajian ibu-ibu hari Minggu malam Senin di rumah salah satu warga.

Adapun metode yang digunakan dalam pemaparan materi adalah bersifat insidental mengingat di masa pandemi covid aparat menghindari kerumunan sehingga pemaparan materi dilaksanakan dengan singkat dalam posisi berdiri dengan kostum pakaian olah raga. Sedangkan sesi lanjutan dilaksanakan di minggu berikutnya di rumah warga dengan memanfaatkan kegiatan pengajian ibu-ibu. Meskipun suasana masih sangat berbahaya untuk berkumpul warga tidak lalai menggunakan APD dan tetap menjalankan protocol kesehatan.

Materi yang disampaikan juga menyesuaikan dengan kondisi, karena rencana pendampingan yang seyogyanya dilaksanakan untuk mendukung promosi UMKM secara luring menjadi meluas dengan kepentingan perdagangan secara online. Namun tidak menjadi masalah karena Tim segera melakukan revisi untuk berkas panduan leaflat public speaking yang bisa dimanfaatkan untuk kepentingan penjualan offline maupun online.

Dalam pelaksanaan pendampingan Tim PKM Unissula ikut berbaur dan bergabung dengan melakukan senam sehat bersama warga dan mengikuti pengajian bersama sehingga ketika Tim memaparkan materi warga sudah tidak merasa canggung lagi. Ketua Tim membuka acara dengan kalimat pengantar menyampaikan maksud dan tujuan dilaksanakannya acara pengabdian masyarakat. Acara berikutnya adalah inti acara berupa pemaparan materi tentang pemanfaatan keterampilan public speaking dalam mendukung optimalisasi kegiatan usaha UMKM warga. 
Tanggapan warga cukup antusias, terbukti mereka dengan senang hati dan menyambut dengan wajah ceriah menanggapi kegiatan dengan beberapa pertanyaan. Gedawang adalah mitra kegiatan pengabdian dari Tim selama beberapa tahun ini dengan beberapa kegiatan berbasis pada permasalahan dan kebutuhan warga. Beberapa rangkaian kegiatan Tim pengabdian di Gedawang adalah hasil dari penerapan solusi permasalahan kegiatan periode sebelumnya. Kegiatan yang pernah dilakukan adalah pelatihan komunikasi keluarga, pelatihan public speaking, pelatihan pendidikan media, pendampingan dan sosialisasi program komunikasi. Melalui silaturrahim dengan ketua RW dan pengurun PKK RW Tim sudah familiar melakukan kegiatan di gedawang.

Namun selalu ada kendala dalam pelaksanaan kegiatan meski kendala tidak terlalu berarti. Misalnya karena pelaksanaan di era Pandemi maka kegiatan dibatasi waktu sehingga dirasa kurang optimal karena terbatas pada tanggapan yang penting saja. Demikian juga karena era pandemic dengan posisi yang harus jaga jarak dan pemakaian APD sehingga membatasi proses interaksi karena tidak bisa melihat mimik wajah secara langsung yang bisa memicu miscommunication.

\section{KESIMPULAN}

Kesimpulan dalam pelaksanaan kegiatan ini adalah bahwa persiapan kegiatan apa pun hendaklah dengan persiapan yang matang bahkan perlu difikirkan manajemen krisi ketika tiba-tiba terkendalan wabah dunia maka perlu antisipasi untuk metode pelaksanaan kegiatan. Kegiatan ini telah membuka wawasan sebayak-banyaknya untuk mengantisipasi umpan balik yang tidak terduga. Selain itu, kegiatan ini menandakan bahwa luaran kegiatan dapat tetap dilaksanakan meski dalam kondisi yang darurat sekali pun. Alhasil kegiatan pengabdian semacam sebaiknya dibuat secara berkelanjutan dan terus dijalin silaturahminya karena hubungan yang baik dan dekat akan lebih mudah untuk melakukan negosiasi pelaksanaan kegiatan meski terkendala pandemi. Selain itu, Tim PKM sebaiknya senantiasa mengupayakan agar peaksanaan kegiatan ini dapat memberi solusi terhadap permasalahan warga. Tim perlu menyiapan materi-materi dan metode yang fleksibel untuk dilaksanakan secara daring maupun secara luring. Tak kalah penting lagi, harus ada upaya dari pelaksana kagiatan untuk menghasilkan temuan yang mampu menghasilkan hak cipta.

\section{UCAPAN TERIMA KASIH}

Rasa syukur dan ucapan terima kasih yang tiada terhingga kepada pihak-pihak yang memudahkan terselenggaranya kegiatan pengabdian kepada masyarakat ini: Universitas Islam Sultan Agung melalui Lembaga Penelitian dan Pengabdian Masyarakat dengan program-program dan bantuan dananya yang memudahkan dosen mengadakan kegiatan, juga kepada rekan-rekan dosen Fakultas Bahasa dan Ilmu Komunikasi Unissula serta warga masyarakat Gedawang Banyumanik yang berkenan membantu dan mendukung diadakannya kegiatan di wilayah tersebut. 


\section{DAFTAR PUSTAKA}

Aribawa, D. (2016). Pengaruh literasi keuangan terhadap kinerja dan keberlangsungan UMKM di Jawa Tengah. Jurnal Siasat Bisnis, 20(1), 1-13. https://doi.org/10.20885/jsb.vol20.iss1.art1

Arliman, L. (2017). Perlindungan hukum UMKM dari eksploitasi ekonomi dalam rangka peningkatan kesejahteraan masyarakat. Jurnal Rechts Vinding: Media Pembinaan Hukum Nasional, 6(3), 387-402. http://dx.doi.org/10.33331/rechtsvinding.v6i3.194

Chrismardani, Y. (2014). Komunikasi pemasaran terpadu: implementasi untuk UMKM. NeoBis, 8(2), 179-189. https://doi.org/10.21107/nbs.v8i2.472

Fuadi, A. O., \& Mangoting, Y. (2013). Pengaruh kualitas pelayanan petugas pajak, sanksi perpajakan dan biaya kepatuhan pajak terhadap kepatuhan wajib pajak UMKM. Tax \& Accounting Review, 1(1), 18.

Hamdy, H. (2001). Ekonomi internasional - teori dan kebijakan perdagangan internasional. Buku 1, Edisi Revisi. Jakarta: Ghalia Indonesia.

Humaira, I., \& Sagoro, E. M. (2018). Pengaruh pengetahuan keuangan, sikap keuangan, dan kepribadian terhadap perilaku manajemen keuangan pada pelaku UMKM sentra kerajinan batik Kabupaten Bantul. Nominal: Barometer Riset Akuntansi dan Manajemen, 7(1), 96110. https://doi.org/10.21831/nominal.v7i1.19363

Lucas, S. E. (2009). The art of public speaking 11th edition. Boston. Mc. Graw Hill.

Parvis, L. F. (2001). The importance of communication and public-speaking skills. Journal of Environmental Health, 63(9), 44-44.

Raja, F. (2017). Anxiety level in students of public speaking: Causes and remedies. Journal of education and educational development, 4(1), 94-110.

Sudaryanto, Ragimun, \& Wijayanti, R. R. (2013). Strategi pemberdayaan UMKM menghadapi pasar bebas ASEAN: Pusat kebijakan ekonomi makro. Badan Kebijakan Fiskal. Kementerian Keuangan, Jakarta.

Verderber, R. F. Verderber, K. S., \& Sellnow, D. D. (2011). The challenge of effective speaking. Boston: Cengage Learning. Beebe, S. A., \& Beebe, S. J. (2010). Public speaking handbook. Allyn \& Bacon.

Wibowo, D. H., \& Arifin, Z. (2015). Analisis strategi pemasaran untuk meningkatkan daya saing UMKM (Studi pada Batik Diajeng Solo). Jurnal Administrasi Bisnis, 29(1), 59-66. 